\title{
Do mito sacrificial à alquímica união dos opostos: o duplo em "Um desejo e dois irmãos", de Marina Colasanti
}

\section{From the sacrificial myth to the alchemic integration of the opposite: the double in "Um desejo e dois irmãos" by Marina Colasanti}

\author{
Fernando de Moraes Gebra" \\ Tatiara Rodrigues Ferranti ${ }^{* *}$
}

\begin{abstract}
Resumo: No presente trabalho, por meio dos estudos de Otto Rank, entendemos o culto aos gêmeos como uma das concretizações míticas do fenômeno do duplo, devido à crença primitiva da dualidade da alma. O conto "Um desejo e dois irmãos", inserido em Doze reis e a moça no labirinto do vento (1982), de Marina Colasanti, apesar de abordar a temática da luta entre dois irmãos, que desejam os reinos do céu e do mar, apresenta a integração alquímica deles. É esta a perspectiva simbólico-figurativa, presente no conto em pauta, que será analisada, tendo em vista as categorias da enunciação - sujeito, tempo e espaço - propostas pela Semiótica de Greimas. Além disso, este estudo verifica como os desdobramentos no nível discursivo relacionam-se aos mecanismos de construção identitária do sujeito. Palavras-chave: Marina Colasanti. Identidade. Duplo. Gêmeos. Herói.

Abstract: Through Otto Rank's studies it is possible to understand the cult to the twins as one of the mythic symbols of the double related to a primitive belief of the soul dualism. The short story "Um desejo e dois irmãos", inserted in Doze reis e a moça no labirinto do vento (1982) by Marina Colasanti refers to the fight between two brothers who want the sky and the sea kingdoms, but it also shows the alchemic integration of the two brothers. This is the symbolic-figurative perspective analyzed in this short story, considering the categories of enunciation - subject, time and space - present in Greimas's Semiotics. Moreover, the study analyses how the discursive level relates to the mechanisms of identity construction.

Keywords: Marina Colasanti; Identity; Double; Twins; Hero.
\end{abstract}

\footnotetext{
" Professor Doutor. Universidade Federal da Integração Latino-Americana (UNILA) e coordenador dos projetos Poéticas da modernidade: $\mathrm{O}$ duplo em contos brasileiros do século XX e Cinescrevendo: $\mathrm{O}$ cinema e as práticas identitárias. E-mail: fernandogebra@yahoo.fr

** Bacharel em Comunicação Social, com habilitação em Jornalismo pela Universidade da Amazônia (UNAMA); graduanda em Letras, com habilitação em Língua Portuguesa pela Universidade Federal do Pará (UFPA) e bolsista PARD - Universidade Federal do Pará. E-mail: tatiaraferranti@hotmail.com
} 
Eu não sou eu nem sou outro Sou qualquer coisa de intermédio,

Pilar da ponte de tédio,

Que vai de mim para o outro.

(Mário de Sá-Carneiro)

O poema acima traduz o que seria a teoria do Duplo elaborada por Sigmund Freud, Otto Rank e Clément Rosset. Esse eu intermediário de que fala o poema consiste na fusão do eu com o Outro. O próprio posicionamento filosófico de Clément Rosset, no livro $O$ real e seu duplo: ensaio sobre a ilusão, faz remissão à estrutura paradoxal do Duplo, visível no trecho deste poema de Mário de Sá-Carneiro: "a noção de duplo, como veremos, implica nela mesma um paradoxo: ser ao mesmo tempo ela própria e outra” (2008, p. 24).

Nos textos em que o fenômeno do duplo se faz presente, as estruturas sêmio-narrativas e discursivas se duplicam. A Semiótica de Greimas estabelece um percurso gerativo de sentido, mostrando como se interpreta o sentido de um texto do nível mais complexo e concreto ao mais simples e abstrato. Enquanto as estruturas narrativas apontam para um actante desdobrado que pode ocupar várias funções actanciais ao mesmo tempo (sujeito e anti-sujeito, sujeito e destinador-manipulador, sujeito e destinador-julgador), as estruturas discursivas, ao partir do pressuposto de uma relação de implicatura entre enunciação (o contexto de produção do discurso) e enunciado (o texto produzido), distingue proximidades e distanciamentos do enunciado em relação à enunciação.

As relações entre enunciação e enunciado são analisadas pela Sintaxe Discursiva. De acordo com a Semiótica greimasiana, a enunciação pode ser definida como o ato de produção do discurso, uma instância pressuposta pelo enunciado (produto da enunciação), ou ainda uma instância de mediação entre as estruturas narrativas e discursivas, que deixa marcas espalhadas no discurso que constrói. Cabe, então, à sintaxe discursiva analisar essas marcas da enunciação deixadas no enunciado, bem como as relações entre o enunciador e o enunciatário do discurso produzido.

Como a enunciação se define a partir do eu-aqui-agora, ela instaura o discurso, projetando fora de si os atores do discurso e as coordenadas espácio-temporais, resultando em uma operação chamada debreagem. Dessa forma, 
ao construir o discurso, a enunciação faz projeção das categorias de pessoa, tempo e espaço, resultando, respectivamente, nos estudos da actoralização, temporalização e espacialização dentro de um texto, relacionadas à proximidade e ao distanciamento dessas categorias relativas à enunciação. "Estudar as projeções da enunciação é, por conseguinte, verificar quais os procedimentos utilizados para constituir o discurso e quais os efeitos de sentido fabricados pelos mecanismos escolhidos" (Barros, 2001, p. 54).

Encontramos três tipos de projeção da enunciação ou debreagem, segundo os efeitos de sentido gerados. Quando se quer gerar um efeito de sentido de proximidade da enunciação ou de subjetividade, revelando um eu no interior do discurso, ocorre uma debreagem enunciativa (projeção do eu-aqui-agora). Se quisermos gerar um efeito de sentido de distanciamento da enunciação ou de objetividade, revelando um eu ausente no discurso, ocorre uma debreagem enunciva (projeção do ele-então-lá). Outro tipo de debreagem comum na construção de diálogos e no estabelecimento de interlocutores são as debreagens internas ou de segundo grau, que ocorrem quando o enunciador dá a palavra a uma das pessoas do enunciado ou da enunciação já instaladas no enunciado, ou a ele mesmo (debreagem enunciativa interna) ou a outra pessoa (debreagem enunciva interna). Tal debreagem cria a ilusão de realidade ou referente, ou seja, tem-se a impressão de que os fatos contados realmente aconteceram. Esses tipos de debreagem podem ser relacionados com as estruturas duplicadas.

"Ao estudarmos estruturas duplicadas, estabelecemos os desdobramentos actanciais (desdobramento de personalidade), temporais (fuga da realidade e busca de um passado de plenitude) e espaciais (fuga do mundo sensível e busca de outros mundos possíveis, tanto o mundo inteligível como os ilusórios, propiciados por mecanismos de cegueira voluntária, relacionados com álcool e drogas)". (GEBRA, 2009, p. 88).

As debreagens apontam para as categorias de pessoa, tempo e espaço. Como a noção de duplo implica no paradoxo, pode ser ao mesmo tempo uma coisa e outra, um espaço e outro, um tempo e outro. O duplo pode, pois, ser idêntico e diferente, ao mesmo tempo em que representa o interior e o exterior do sujeito, o espaço do aqui e o espaço do lá, gerando, no nível narrativo do texto, no percurso passional do sujeito, relações de atração e repulsa. Segundo Diana Luz Pessoa de Barros: 
"As paixões, do ponto de vista da semiótica, entendem-se como efeitos de sentido de qualificações modais que modificam o sujeito de estado. Essas qualificações organizam-se sob a forma de arranjos sintagmáticos de modalidades ou configurações passionais". (2001, p. 33).

As paixões podem ser simples ou complexas, de acordo com a presença de um ou de vários elementos modais. Se houver apenas o querer, ou seja, o sujeito deseja ou não uma mudança de estado, haverá uma paixão simples. Se houver um encadeamento de situações ou de modalidades (querer, dever, saber e poder), haverá uma paixão complexa.

A temática do Duplo, também presente na organização das paixões ambivalentes dos actantes das narrativas, é visualizada no conto "Um desejo e dois irmãos", inserido no livro Doze reis e a moça no labirinto do vento (1982), de Marina Colasanti. A história apresenta uma narrativa instigante quanto à temática do Duplo. Neste conto, "Dois príncipes, um louro e um moreno" (2001, p. 49), um de olhos verdes e outro de olhos azuis, irmãos e "tão diferentes nos gostos e nos sorrisos" (ibidem), mas tão comuns no desejo de um ser o outro, resolvem fazer uma disputa para conquistar o presente dado pelo pai a cada um deles - os reinos do céu e do mar.

Insatisfeitos com o presente que, em tese, colocaria fim à disputa entre ambos, os príncipes resolvem fazer uma competição. Quem atingisse primeiro a linha do horizonte, venceria a competição e dominaria o reino todo. Porém, no final do conto, quando o narrador anuncia o vencedor, uma grande surpresa envolve o leitor: quem conquista o reino não é nem um nem outro príncipe. É um só, o intermediário, ou seja, "O Outro" de que fala Mário de Sá-Carneiro. O ser duplicado, portanto.

Podemos entender as figuras actorais dos dois príncipes como participantes de um mesmo ritual de autoconhecimento, dentro do nível narrativo, com funções actanciais estudadas por Greimas, tomadas por base no modelo dos contos maravilhosos descritos por Vladimir Propp.

As estruturas narrativas de "Um desejo e dois irmãos" seguem, até certo ponto, o modelo proppiano dos contos de fada: há um sujeito que precisa passar por provas e superar obstáculos para realizar a ação principal e obter um prêmio no final. O conto inicia com uma situação inicial de desequilíbrio: um gêmeo quer ser o outro, quer ter o lugar do outro. O pai resolve dividir o reino, acreditando pôr termo ao conflito que envolve os dois filhos. O problema, 
que poderia ter se resolvido mediante aquisição de um objeto-valor (cada filho recebe uma parte do reino), só tende a piorar, até que um desafio é feito: aquele que chegasse primeiramente à linha do horizonte seria o senhor de todo o reino. Temos aqui elementos dos arquétipos primitivos de que a morte de um dos gêmeos garantiria a imortalidade e a soberania do outro, resultando na fundação de uma cidade, neste caso, na unicidade do reino herdado, que se encontrava dividido entre os dois irmãos.

No entanto, Marina Colasanti rompe a estrutura dos mitos sacrificiais em relação aos gêmeos. Por meio da interferência da linha do horizonte, elemento sobrenatural personificado na estrutura do conto, os dois príncipes se fundem e se tornam um só, consciente agora da sua identidade múltipla.

No início da narrativa, é visível como um irmão quer ser o outro, apesar da diferença física entre ambos: "uma coisa porém tinham em comum: cada um deles queria ser o outro" (2001, p. 49). Esse desejo obcecado pela imagem do outro e por tudo que esse outro almeja ou faz permite que ambos os irmãos se esqueçam "de olhar para si, de serem felizes" (ibidem). Logo, o encanto exacerbado pelo outro anula a felicidade dos irmãos.

Vários fragmentos do conto de Marina exemplificam a questão do olhar para o outro como se esse outro fosse o melhor, como se o sentido para vencer e para realizar-se estivesse no irmão e em seus bens, e não em si próprio. Essa ideia é sustentada pelo desejo dos dois irmãos de conquistar aquilo que é do outro, o reino todo. Várias passagens comprovam esse posicionamento, a exemplo do trecho que descreve o momento da ânsia de um irmão em não se contentar com o seu reino e ir buscar naquilo que é do outro o sentido para a vida:

A cada um, seu reino. Mas as pernas que roçavam em plumas esporearam o cavalo para baixo, em direção às cristas das ondas. E os joelhos que apertavam os flancos molhados ordenaram que subisse, junto à tona. (COLASANTI, 2001, p. 49).

Dentro desta perspectiva, Clément Rosset ressalta que o sentido da existência está no outro, ou seja, no duplo. É por isso que o fascínio de ambos os príncipes é assegurado pelas atitudes do outro e pela vontade de ser o outro, e não eles mesmos: "O sentido é justamente o que é fornecido não por ele mesmo, mas pelo outro" (2008, p. 74). Em outras palavras, a construção da identidade dos irmãos é assegurada pelo confronto com o duplo, pela relação com o outro. 
Esse embate com o outro causa um "desejo insatisfeito", ameaça a estabilidade dos irmãos, numa repulsa constante de estranhamento entre eles. Ao mesmo tempo, cria um total desejo de um príncipe ser o outro, de possuir aquilo que é do outro, neste caso, o reino. Logo no início do conto ambos os irmãos acreditam e interiorizam que tudo do outro é melhor.

E dominar os bens do outro é satisfazer a si próprio, é garantir sentido e prazer à vida. Isto acontece porque os príncipes estão lutando com a sua própria personalidade. Eles representam a imagem duplicada, ou seja, o duplo, o desdobramento de si mesmo, que é ratificado, inclusive, no final do conto e nos períodos cujos paralelismos são visíveis:

Do ar, o príncipe das nuvens olhou através do seu reflexo, procurando a figura do irmão nas profundezas.

Da água, o jovem senhor das vagas quebrou com seu olhar a lâmina da superfície procurando a silhueta do irmão.

O de cima sentiu calor, e desejou ter o mar para si, certo de que nada o faria mais feliz do que mergulhar no seu frescor.

O de baixo sentiu frio, e quis possuir o céu, certo de que nada o faria mais feliz do que voar na sua mornança. (idem, p. 49-50).

Encontramos neste fragmento estruturas paralelas, marcadas por relações sinonímicas e antitéticas. Para efeito de visualização e descrição sêmico-estrutural, optamos por destacar, primeiramente, as estruturas sinônimas, para depois discutir as estruturas antitéticas:

Do ar, o príncipe das nuvens olhou através do seu reflexo, procurando a figura do irmão nas profundezas.

Da água, o jovem senhor das vagas quebrou com seu olhar a lâmina da superfície procurando a silhueta do irmão. (ibidem; grifos nossos).

Temos três pares de estruturas paralelas sinonímicas: 1) olhou / quebrou com seu olhar; 2) reflexo / lâmina; 3) procurando a figura do irmão / procurando a silhueta do irmão. As palavras figura e silhueta apresentam equivalência semântica, pois indicam a imagem do outro refletida, tal como o espelho, objeto de reflexão da imagem, que apresenta uma superfície refletora. Pela dinâmica do olhar ou da quebra do olhar, percebe-se a intensidade do desejo de cada um dos príncipes de querer ser o outro. Se os sintagmas do olhar, do reflexo, da procura e da figura são correlatos e se encontram de forma paralela, o que dizer do sintagma referente às duas figuras de ordem espacial? 
Do ar, o príncipe das nuvens olhou através de seu reflexo procurando a figura do irmão nas profundezas.

Da água, o jovem senhor das vagas quebrou com seu olhar a lâmina da superfície procurando a silhueta do irmão. (ibidem, grifos nossos).

O narrador, ao estabelecer uma homologação entre os outros sintagmas por meio do paralelismo sintático e semântico, sugere também uma correspondência de sentido entre os espaços do ar e da água, estruturas sobre-humanas caracterizadoras de cada um dos príncipes. Esses espaços, ainda que se oponham na sua dimensão vertical (alto e baixo), apresentam similitudes, ao se constituírem reflexo um do outro, como aponta o poema "Mar português", de Fernando Pessoa: "Deus ao mar o perigo e abismo deu / Mas nele é que espelhou o céu". Além disso, ambos os espaços constituem a estrutura paradoxal do duplo: ser, ao mesmo tempo, uma coisa e outra, o que explica o uso das estruturas paralelas.

O de cima sentiu calor, e desejou ter o mar para si, certo de que nada o faria mais feliz do que mergulhar no seu frescor.

$O$ de baixo sentiu frio, e quis possuir o céu, certo de que nada o faria mais feliz do que voar na sua mornança. (idem, p. 50, grifos nossos).

Como podemos visualizar no fragmento, cada parágrafo se refere a um dos príncipes e apresenta as seguintes estruturas paralelas: 1) sentiu / sentiu;2) e desejou ter / e quis possuir; 3) certo de que nada o faria mais feliz do que / certo de que nada o faria mais feliz do que. Dos três pares de estruturas paralelas, o primeiro e terceiro são absolutamente idênticos, e o segundo apresenta duas estruturas paralelas sinônimas, pois desejou ter equivale a quis possuir, já que apresenta a modalidade volitiva, a instauração do desejo, o querer-fazer, como elemento de competência do sujeito, necessário para a realização da performance, ou ação principal. Segundo Diana Luz Pessoa de Barros:

A competência, entendida como as condições necessárias à realização da performance, é sempre um programa de uso em relação ao programa da performance. Caracteriza-se como uma organização hierárquica de modalidades ou de valores modais: o querer-fazer elou o dever-fazer regem o poder-fazer elou o saber-fazer. (1988, p. 35).

Por um lado, se o fragmento apresenta estruturas paralelas idênticas ou marcadas pela sinonímia, também possui estruturas antitéticas, como se pode visualizar abaixo no mesmo trecho: 
O de cima sentiu calor, e desejou ter o mar para si, certo de que nada o faria mais feliz do que mergulhar no seu frescor.

O de baixo sentiu frio, e quis possuir o céu, certo de que nada o faria mais feliz do que voar na sua mornança. (COLASANTI, 2001, p. 50, grifos nossos).

Observamos os seguintes pares antitéticos: 1) o de cima/o de baixo; 2) calor/frio; 3) céu/mar; 4) mornançalfrescor. Os primeiros elementos de cada par (o de cima, calor, céu, mornança) fazem parte do percurso figurativo espacial e actoral do alto, referente ao príncipe louro, enquanto os outros ( $o$ de baixo, frio, mar, frescor) pertencem ao percurso figurativo do baixo, do príncipe moreno. Antes da irrupção do desejo, figurado pelas expressões e desejou ter e e quis possuir, encontramos a insatisfação de cada um dos príncipes, figurada na reiteração do verbo sentir, anteposto às sensações térmicas de calor e de frio. $\mathrm{O}$ desejo de cada um é sentir aquilo que o outro rejeita: um quer sentir o frio, visto como frescor, enquanto o outro deseja o calor, entendido como mornança. Para cada um, a sensação térmica proveniente do espaço em que ocupam ( $o$ de cima / o de baixo) recebe qualificação disfórica, pois os príncipes desejam o que é do outro, atenuando a sensação térmica buscada: o calor e o frio são vistos pelos sujeitos desejantes, respectivamente, como mornança e frescor.

Seguindo um modelo greimasiano, Salvatore D’Onófrio estabelece uma classificação dos espaços. Para ele, os espaços podem ser verticais quando se referem ao alto (deuses superiores) e ao baixo (entidades infernais), e horizontais quando se situam na esfera do humano. Neste caso, podem ser tópicos, atópicos e utópicos. O primeiro refere-se ao espaço da segurança, do conhecido; o segundo, ao lugar estranho e hostil; e o terceiro, à idealização (2007, p. 82). Em "Um desejo e dois irmãos", os espaços verticais não se referem aos deuses superiores e às entidades infernais, mas sim às dimensões simbólicas e metafísicas do ser.

Como observamos em contos de Marina Colasanti, a autora foge aos paradigmas do senso comum e propõe novas leituras de aspectos míticos e arquetípicos fundamentais do ser humano. Cada elemento espacial apresenta uma dimensão simbólica na travessia do espaço tópico (a segurança dos gêmeos na companhia do pai antes da partilha do reino) para o espaço atópico (a prova ritualística da travessia em direção à linha do horizonte), com a chegada ao espaço utópico (a dimensão metafísica resultante do processo de autoconhecimento travado com o duplo). 
Torna-se importante, desta forma, compreender qual a relação simbólica existente entre os elementos da natureza (espacialização) e o conto. O reino do mar - presente dado a um dos irmãos como tentativa de acabar com o conflito entre os príncipes - apresenta uma significação relevante para a compreensão da narrativa. Segundo o Dicionário de símbolos, o mar é o símbolo da dinâmica da vida. "Tudo sai do mar e tudo retorna a ele: lugar dos nascimentos, das transformações e dos renascimentos". (CHEVALIER; GHEERBRANT, 2005, p. 592). Logo, pode-se afirmar que a água foi o elemento de transformação do ser, da vida de ambos os príncipes:

E as asas brancas do cavalo alado, pesadas de sal, entregaram-se à água, a crina branca roçando já o pescoço do hipocampo. Desfez-se a carruagem de nuvens na crista da última onda. Onda que inchou, rolou, envolvendo os irmãos num mesmo abraço. (COLASANTI, 2001, p. 53, grifos nossos).

Portanto, foi no mergulho nas águas que a união dos irmãos integrou um único príncipe, transformou e renasceu nos irmãos a integridade da alma. As ondas, como sustentam o destaque acima, também representam uma essencial simbologia para o conto. "O mergulho nas ondas indica uma ruptura com a vida habitual: mudança radical nas ideias, nas atitudes, no comportamento, na existência", conforme o Dicionário de Símbolos (CHEVALIER; GHEERBRANT, 2005, p. 658).

Nesse sentido, é por meio do mar e das ondas e é nesse cenário tão simbólico que a mudança radical se afirma no conto "Um desejo e dois irmãos": a aceitação do duplo como integridade indispensável do ser. De acordo com o contexto, a água é fonte de vida e de purificação, por isso que representa o batismo, nas tradições religiosas, tal como propõe o Dicionário de símbolos:

As significações simbólicas da água podem reduzir-se a três temas dominantes: fonte de vida, meio de purificação, centro de regenerescência. Esses três temas se encontram nas mais antigas tradições e formam as mais variadas combinações imaginárias - e as mais coerentes também. (CHEVALIER; GHEERBRANT, 2005, p. 15).

Aceitar a realidade é olhar o duplo como unidade do ser. Não é à toa que "o olhar é como o mar, mutante e vibrante, reflexo ao mesmo tempo das profundezas submarinas e do céu”, afirma o Dicionário de Símbolos (CHEVALIER; GHEERBRANT, 2005, p. 653). Nessa perspectiva, os olhos 
dos gêmeos, que se tornam castanhos no final do conto, refletem o presente dado a eles pelos pais, o céu e o mar.

Essa relação entre alto e baixo, ou seja, entre céu e mar, que é apresentada em "Um desejo e dois irmãos" também tem relação com o outro presente dado aos gêmeos pelo rei, o cavalo:

De tudo o que tinha, deu o céu para seu filho louro, que governasse junto ao sol brilhante como seus cabelos. E entregou-lhe pelas rédeas um cavalo alado. Ao moreno coube o verde mar, reflexo de seus olhos. E um cavalo-marinho. (idem, p. 49).

De acordo com o Dicionário de Símbolos, o cavalo, suporte de disputa dos irmãos, é universal porque está ligado aos dois polos do universo. Além disso, ele é associado às majestades: "o cavalo é o símbolo da majestade". Nesse sentido:

[...] vê-se que o cavalo constitui um dos arquétipos fundamentais dentre os que a humanidade inscreveu em sua memória. Seu simbolismo estende-se aos dois polos (alto e baixo) do Cosmo, e por isso é realmente universal. No mundo de baixo, o octoniano, vimos efetivamente que o cavalo parece como um avatar ou um amigo dos três elementos constituintes desse mundo - fogo, terra, água - e de seu luminar, a Lua. Mas nós o vimos também no mundo de cima, o uraniano, associado a seus três elementos constituintes - ar, fogo e água - (sendo esses dois últimos compreendidos, desta vez, em sua acepção celeste), e ao seu luminar, o Sol. No frontão do Partenon, são cavalos que puxam tanto o carro do Sol como o da Lua. O cavalo passa com igual desenvoltura da noite ao dia, da morte à vida, da paixão à ação. Religa, portanto, os opostos numa manifestação contínua. (CHEVALIER; GHEERBRANT, 2005, p. 211).

Pode-se assegurar que os cavalos dos dois irmãos, assim como o objeto purificador do ser - a água - uniu os opostos, ou seja, os dois príncipes numa perfeita harmonia. Fernando Pessoa, no poema "Mar português", enfatiza, inclusive, a figuração do duplo na imagem do mar que refletiu o céu: "Deus ao mar o perigo e o abismo deu / Mas nele é que espelhou o céu". Logo, sem o mar o céu não existiria, assim como sem um irmão a existência do outro seria impossível.

O poema de Pessoa se encontra em Mensagem, único livro em língua portuguesa que o autor publicou em vida. Lá, encontramos os heróis, tanto 
na dimensão épica como trágica, que foram responsáveis pela construção identitária da pátria: "Para que fosses nosso, ó mar!". O mar, símbolo das conquistas e do poderio naval dos portugueses, pode ser lido, na sua dimensão simbólica, como síntese das grandes transformações, movimento eterno de nascimento e renascimento. São as ondas do mar que incham e envolvem os dois príncipes num mesmo abraço, "juntando para sempre aquilo que era tão separado" (COLASANTI, 2001, p. 53).

Os heróis do conto de Marina Colasanti, assim como os heróis de Mensagem, passam por provas que os qualificam enquanto seres eleitos, com poderes sobrenaturais de fundir céu e mar, de realizar a travessia interior no difícil processo de autoconhecimento.

De acordo com o Dicionário de Símbolos, os atos heroicos estão atrelados à figuração do príncipe. "Ele faz mais o gênero do herói do que do sábio. A ele pertencem os grandes feitos, mais que a manutenção da ordem" (CHEVALIER; GHEERBRANT, 2005, p. 744). Mas é importante compreender que o ato heroico, ou seja, o domínio do cosmo, só é garantido pelo reconhecimento de que um príncipe não vive sem o outro e não é herói sozinho. Portanto, o heroísmo se dá em decorrência do amor ao irmão e da soma das virtudes de ambos que anula a disputa e a derrota de um dos irmãos.

Em "Um desejo e dois irmãos", os dois príncipes são representações dos gêmeos e é neles que se manifesta o duplo. Ana Maria Lisboa de Mello, no ensaio "As faces do duplo na literatura", esclarece em quais figurações o Duplo pode aparecer nas obras literárias:

Na criação literária, a cisão do Eu pode apresentar-se sob múltiplas formas, desdobrando-se em sósias, irmãos - gêmeos ou não - representada, também, pela sombra, o retrato ou a imagem refletida no espelho. Os duplos mais antigos apresentam-se geralmente sob a forma de gêmeos ou irmãos próximos, como Castor e Pólux, Helena e Cliptemnestra, Caim e Abel, ou de sósias, como Anfitrião, personagem da mitologia grega que se tornou célebre em peça de Plauto. (2000, p. 113).

No caso do conto analisado, o duplo é figurativizado por meio da existência dos irmãos gêmeos. Compreender a relação entre os irmãos da narrativa é essencial para compreender como Marina Colasanti desconstrói a perspectiva sacrificial de um dos gêmeos, tão vigorada em várias tradições culturais primitivas. Otto Rank defende que "devemos encarar o culto aos 
gêmeos como uma concretização mítica do tema sobre o Duplo, e que este fato provém da crença numa alma dupla - mortal e imortal" (1939, p. 136).

Nesse sentido, os gêmeos eram considerados seres poderosos por virem ao mundo com seu duplo. Cada um deles representava um aspecto da alma e eram diretamente ligados à fundação de cidades. Conforme os credos primitivos, era necessário o sacrifício de um dos gêmeos para assegurar o ato heroico, como é visto, inclusive, nas experiências de vida de vários irmãos gêmeos.

A história de Romulus e Remus, de Anphion e Zethos, de Caim e Abel, demonstra que, nestes pares de gêmeos, um deles foi assassinado e o outro se tornou o fundador de uma cidade. Não resta dúvida que devemos ver nesse assassinato a ideia do sacrifício oportuno, ocasionado pela construção de uma cidade ou de uma casa. (RANK, 1939, p. 140).

Assim, um dos gêmeos representaria a alma mortal que deveria perecer para que o outro gêmeo tivesse assegurada sua imortalidade. Só assim poderia ocorrer o feito heroico, como a fundação das cidades.

O entusiasmo causado pelo final inesperado e criativo do conto só é assegurado pela desconstrução desse mito sacrificial dos gêmeos. Para Otto Rank, em algumas tradições sul-americanas, "os gêmeos só conseguiam praticar atos heroicos, quando juntos, porque era justamente a sua união, que lhes assegurava a sua imortalidade" (idem, p. 144).

Na narrativa analisada, apesar de haver a disputa entre os irmãos pela conquista íntegra do universo, é a alquímica união dos opostos, no caso, dos gêmeos, e não o sacrifício de um dos irmãos em detrimento do outro, que garante a imortalidade deles e o sentido da vida, como se pode observar nos dois últimos parágrafos do conto:

Desfez-se a carruagem de nuvens na crista da última onda. Onda que inchou, rolou, envolvendo os irmãos num mesmo abraço, jogando um corpo contra o outro, juntando para sempre aquilo que era tão separado.

Desliza a onda sobre a areia, depositando o vencedor. Na branca praia do horizonte, onde tudo se encontra, avança agora um único príncipe, dono do céu e do mar. De olhos e cabelos castanhos, feliz, enfim. (p. 53).

Dessa forma, o outro é necessário para a integridade do Eu, ou seja, dos dois irmãos. Sem o outro, perde-se a identidade, perde-se a essência do ser. 
É preciso jogar "um corpo contra o outro" e juntar "para sempre aquilo que era tão separado" para, enfim, atingir a felicidade, a completude e o sentido da vida.

No conto "Um desejo e dois irmãos", o desdobramento de personalidade aparece na figura dos dois irmãos, que, como vimos, se passam por gêmeos. Péricles (apud Melo) acredita que predominam três relações do ser humano com o duplo:

1) A vida de um depende da do outro; 2) Os sentimentos de um têm ressonância no Outro, mas não são obrigatoriamente os mesmos ; 3) os conhecimentos de um podem-se apresentar na consciência do duplo, que pode deles fazer um uso diferente. (2000, p. 119).

Na narrativa analisada, as três relações acima são válidas para configurar a relação do sujeito com seu duplo. Logo, a vida de um príncipe depende da vida do outro; os sentimentos de um são os mesmos do outro ("nessa segunda coisa também eram iguais, no desejo de vencer") e os saberes de um irmão estão na consciência do outro.

Neste caso do conto de Marina Colasanti, os gêmeos duplicam-se não para estabelecer a rivalidade entre ambos, mas sim para completar a personalidade em construção. A harmonia dos opostos é que garante a felicidade e a completude do ser. Ana Maria Lisboa de Melo defende, neste sentido, que "a unidade psíquica alcançada é resultado do processo de individualização que, segundo C. G. Jung, implica a harmonia dos opostos e significa o tornar-se si-mesmo ou o realizar-se do si-mesmo" (2000, p. 122).

Assim, a realização e a configuração da identidade dos príncipes ocorrem pela fusão de ambos, pela unicidade do ser, que não é mais de olhos azuis e verdes, e nem loiro e moreno, mas de olhos e cabelos castanhos: "Desliza a onda sobre a areia, depositando o vencedor. Na branca praia do horizonte, onde tudo se encontra, avança agora um único príncipe, dono do céu e do mar. De olhos e cabelos castanhos, feliz enfim" (2001, p. 53).

O castanho representa, pois, a fusão das duas cores e a conclusão de que a composição da identidade dos irmãos é assegurada pela presença do outro, ou seja, do seu duplo. Portanto, o ato heroico do conto de fadas em questão consiste justamente em admitir que a felicidade do ser está em aceitar o seu duplo e em reconhecer que ele faz parte da configuração da identidade do ser. Em outras palavras, anular o duplo significa anular a própria vida e a própria identidade. Disputar contra a própria personalidade é alcançar o fracasso. 
Por meio da noção do duplo, toda a problemática da identidade pessoal, da busca do Eu profundo de que fala Ana Maria Lisboa de Mello é desvendada. Em "Um desejo e dois irmãos", o Eu profundo só é assegurado pela autocompreensão e unidade interna do eu, que se constitui pela imagem fundida dos gêmeos, que na verdade são um só.

Conforme o Dicionário de mitos literários, o duplo põe à tona a questão da identidade do ser, já que só conseguimos conhecer nosso interior, nosso Eu profundo, quando nos deparamos com nossa réplica (BRAVO, 2000, p. 267). Nesse sentido, os dois irmãos só conseguem conhecer a si mesmos quando seu duplo se manifesta na presença do outro, nos desejos do outro que, ao mesmo tempo, é o próprio desejo.

É também por isso que o poder dos irmãos de conquistarem o universo está ligado com a figuração do Duplo. Se no final do conto um irmão tivesse matado o outro para conquistar o ato heroico, como é visível em muitas tradições culturais ligadas à fundação de cidades, a felicidade não seria assegurada, pois matar o duplo significa matar a si mesmo, já que o duplo é o original que ele próprio duplica, conforme Clément Rosset.

Logo, o narrador deixa claro no conto que a felicidade dos gêmeos só é alcançada quando há uma fusão entre eles, ou seja, quando ambos reconhecem que a integridade da alma, dos desejos, das conquistas garante a constituição íntegra da identidade do ser.

Nesse sentido, é a dualidade do ser que aflora e deixa transparecer o "único príncipe", que não é mais de olhos verdes e azuis, mas de olhos castanhos, "feliz enfim" e completo. É importante destacar que este novo ser que surge no final do conto não apresenta uma única identidade, mas sim várias identidades constituintes da duplicidade dos dois irmãos. Como em muitos contos de Marina Colasanti, as personagens estão em confronto com a realidade circundante e buscam ultrapassar os limites do conhecimento de si mesmas por meio de desdobramentos e de fragmentações de identidade.

O sujeito está em crise, já que está imerso em uma realidade em crise. Stuart Hall, em A identidade cultural na pós-modernidade, comenta acerca das mudanças estruturais na sociedade contemporânea que provocam alterações nas paisagens sociais e nas configurações identitárias do sujeito. $\mathrm{O}$ sujeito pós-moderno assume identidades diferentes em diferentes momentos. São identidades não mais centradas ao redor de um núcleo estável, pois o 
próprio conceito de pós-modernidade ou de modernidade tardia instaura o paradigma da instabilidade, da incerteza e da dúvida. As identidades passam a ser múltiplas e continuamente transformadas nos sistemas culturais em que estamos inseridos.

Para o referido teórico, "Dentro de nós há identidades contraditórias, empurrando em diferentes direções, de tal modo que nossas identificações estão sendo continuamente deslocadas" (1999, p. 13). No conto em análise, os deslocamentos ocorrem em duas direções: há um vetor ascensional que empurra o príncipe moreno em direção à identidade do príncipe louro. Por outro lado, o príncipe louro é empurrado por um vetor para baixo, em direção à identidade do príncipe moreno.

Segundo Stuart Hall, não existe identidade unificada: "Se sentimos que temos uma identidade unificada desde o nascimento até a morte é apenas porque construímos uma cômoda estória sobre nós mesmos ou uma confortadora 'narrativa do eu'" (1999, p. 13).

Devemos ter, pois, consciência de que, ao sermos interpelados pelos vários sistemas sociais, apresentamos identidades que nos empurram para várias direções, identidades muitas vezes contraditórias, que podem ser figuradas no conto em pauta por meio de estruturas sintáticas paralelas, simultaneamente sinonímicas e antitéticas.

Mas, afinal, por que levantar a questão do duplo e da identidade nos contos de Marina Colasanti, inclusive neste analisado? Simplesmente porque a existência do homem, neste caso, dos gêmeos, do "único príncipe", é confirmada pela identidade, pelo reconhecimento e aceitação do duplo.

Estudar a temática do duplo e compreender como ela se manifesta nos escritos literários e, neste caso, no conto analisado de Marina Colasanti, significa por à tona questões ontológicas inerentes ao ser humano. Significa compreender como a construção identitária dos personagens se manifesta e se desdobra ao longo da narrativa. Rosset observa que a noção do duplo está ligada ao desdobramento de personalidade:

O tema do duplo é, em geral, associado principalmente aos fenômenos de desdobramento de personalidade (esquizofrênica ou paranoica) e à literatura, particularmente à romântica, na qual se encontram múltiplos ecos seus: como se este tema dissesse respeito essencialmente aos confins da normalidade psicológica e, no plano literário, a um certo período romântico e moderno. (2008, p. 24). 
Esse desdobramento de personalidade, referido por Rosset, está relacionado ao processo de autoconhecimento do sujeito. Logo, é necessário haver o duplo para garantir o conhecimento de si mesmo, para assegurar a constituição da identidade dos príncipes do conto.

Ana Maria Lisboa de Mello afirma que o fenômeno do duplo surge como "representação de uma cisão interna", já que no conto os dois irmãos se veem como o outro em face das semelhanças psicológicas existentes entre eles. A autora esclarece também as consequências da presença do duplo na vida do sujeito: "esse encontro pode provocar angústia, mal-estar e medo, nem sempre passíveis de equacionar. Pode significar também o encontro necessário para solucionar a divisão interna e levar ao alcance da unidade" (2000, p. 121-122).

Em quase todo o conto, os gêmeos sofrem de certo mal-estar e medo por não verem a felicidade naquilo que são e que possuem. Eles vivem as angústias de não terem aquilo que é do outro - o reino do céu e do mar. Porém, essa angústia é abolida quando ambos os príncipes se envolvem "num mesmo abraço", integrando um único ser, vencedor, possuidor não só do reino do céu, nem só do reino do mar, mas de todo o cosmos, "feliz enfim".

No final do conto, o duplo não é mais ligado a situações angustiantes e de disputa, mas sim à capacidade de amar, de aceitar o duplo como constituição da própria identidade do príncipe. Assim, a felicidade só é atingida quando há a fusão, a integridade entre a própria personalidade do sujeito e sua réplica, entre um príncipe e outro.

Logo, é a união dos gêmeos que garante a imortalidade deles, como se observa no final da narrativa. No conto, o tema sobre os gêmeos conduz, afinal, à eterna vontade de tornar imortal a personalidade. No final do conto, a aceitação do duplo garante a felicidade, pois recusar o outro implica negar a si mesmo, desprezar o processo do autoconhecimento, que é essencial à vida humana, garantindo a integridade do ser.

\section{Referências}

BARROS, Diana Luz Pessoa de. Teoria do discurso: fundamentos semióticos. São Paulo: Atual, 1988.

. Teoria semiótica do texto. São Paulo: Ática, 2001. 
BRAVO, Nicole Fernandez. Duplo. In: BRUNEL, Pierre (Org.). Dicionário de mitos literários. 3. ed. Rio de Janeiro: José Olympio, 2000.

CHEVALIER, Jean; GHEERBRANT, Alain. Dicionário de símbolos. 19. ed. Coord. Carlos Sussekind. Trad. Vera da Costa e Silva et alli. Rio de Janeiro: José Olympio, 2005.

COLASANTI, Marina. Doze reis e a moça no labirinto do vento. 10. ed. São Paulo: Global, 2001.

D’ONOFRIO, Salvatore. Forma e sentido do texto literário. São Paulo: Ática, 2007.

FIORIN, José Luiz. Elementos de análise do discurso. 10. ed. São Paulo: Contexto, 2001. (Repensando a língua portuguesa).

GEBRA, Fernando de Moraes. Identidades intersubjetivas em contos de Mário de Andrade. Curitiba: UFPR, 2009. (Tese de Doutorado).

HALL, Stuart. A identidade cultural na pós-modernidade. Rio de Janeiro: DP\&A, 1999.

MELLO, Ana Maria Lisboa de Mello. As faces do duplo na Literatura. In. INDURSKY, Freda; CAMPOS, Maria do Carmo. Discurso, memória, identidade. Porto Alegre: Sagra Luzzatto, 2000.

PESSOA, Fernando. Obra poética. 17. reimp. da 3. ed. Organização, introdução e notas de Maria Aliete Galhoz. Rio de Janeiro: Nova Aguilar, 1999. p. 69-89.

RANK, Otto. O duplo. Trad. Mary B. Lee. 2. ed. Rio de Janeiro: Alba, 1939.

ROSSET, Clément. O real e seu duplo: ensaio sobre a ilusão. Apres. e trad. José Thomaz Brum. 2. ed. Rio de Janeiro: José Olympio, 2008.

Recebido para publicação em 8 nov. 2010. Aceito para publicação em 30 mar. 2011. 